\title{
The Impact of Selected Sewage Treatment Methods on the Change in Parameters of Sewage Sludge Originating from Municipal Sewage Treatment Plants
}

\author{
Hanna Bauman-Kaszubska ${ }^{*}$, Mikołaj Sikorski' \\ 1 Faculty of Civil Engineering, Mechanics and Petrochemistry, Warsaw University of Technology, Łukasiewicza 17, \\ 09-400 Płock, Poland \\ * Corresponding author's e-mail: Hanna.Bauman@pw.edu.pl
}

\begin{abstract}
Sewage sludge is produced in every sewage treatment plant and its properties depend on a number of factors. The type, origin and parameters of the treated sewage and the applied treatment technology are the main factors influencing the sludge properties. The produced sewage sludge can be submitted to treatment processes which condition its final use. For example, the sludge produced in small treatment plants, treating mainly domestic sewage, can be used for agricultural purposes. This paper presents the results of the authors' own research on the susceptibility of sludge originating from several municipal wastewater treatment plants to selected treatment processes and changes in properties as a result of the carried out processes. The obtained results confirm that the ultrasonic field, as a physical method of sewage sludge modification, is a factor intensifying the drainage processes. In most cases, the investigations have shown better results of the dewaterability of sludge treated with ultrasonic field in relation to raw sediments. For the tested sediments, it is justified to use the centrifugation process as a method of mechanical compaction.
\end{abstract}

Keywords: sewage sludge, dewatering, ultrasonic disintegration, vacuum filtration

\section{INTRODUCTION}

Sewage sludge management carried out in municipal wastewater treatment plants is determined by the quantitative (capacity of a plant) and qualitative structure of the generated sludge, legal circumstances and local conditions. Apart from the technological aspects, both the running and investment costs play the most important role here. According to the data provided by the Polish Central Statistical Office (Statistical Yearbooks of the Central Statistical Office, 2017), in 2016 the municipal sewage treatment plants in Poland produced 568.3 thousand $\mathrm{Mg}$ of dry weight of sewage sludge, which constitutes a rise of $300 \mathrm{Mg}$ in comparison to 2015 and a rise of 12.3 thousand $\mathrm{Mg}$ of dry weight in comparison to 2014. The data contained in the report on the implementation of the National Sewage Treatment Programme in the period from 2014-2015 (National Water Manage- ment Authority, 2016) show that the amount of the produced and deposited dry weight of sewage sludge originating from wastewater treatment plants in 2014 and 2015 amounted to $600078 \mathrm{Mg}$ and $590199 \mathrm{Mg}$, respectively. A sustained growth in the amount of produced sewage sludge is caused by increasing the capacity of municipal wastewater treatment plants and the employment of more and more advanced technologies of increased nutrient removal.

Both the data from the Polish Central Statistical Office (CSO) and National Water Management Authority (NWMA) indicate a very limited degree of sludge use in agriculture, land reclamation and cultivation of the plants intended for compost production. Approximately $20 \%$ of sludge in total, produced in municipal wastewater treatment plants, is used for the above mentioned purposes. However, for today's needs, this is still not enough - nearly $15 \%$. One should not 
expect that the situation in this case will improve quickly, mainly because of high investment costs of installations for incineration of sewage sludge.

Because of their physical and chemical properties and threats it can pose for the environment and human health, the sewage sludge produced in municipal wastewater treatment plants has to undergo proper treatment. It should be disposed of in order to decrease its fouling rate in the stabilization process, destroy pathogenic organisms in the hygienisation process, as well as reduce the volume and weight of sludge in the dehydration and drying processes. Sewage sludge treatment should be carried out in such a way so as to obtain the sludge with the properties enabling its further safe management (Fukas-Płonka et al., 2013). The basis for classification of sludge to treatment methods is chemical composition, sanitary condition and physical properties. Sewage sludge can be a source of valuable nutrients necessary for plant growth (Wiater and Butarewicz, 2014). Its application improves the physical and chemical properties of soil and exerts influence on the increase of organic matter in soil (Grobelak et al., 2016; Obbard, 2001; Świsłowski, 2016). The greatest difficulty connected with using sewage sludge in nature is the high content of heavy metal, highly toxic chemicals and pathogenic organisms (Krzywy et al., 2015). When administering sewage sludge into soil, the excess of heavy metals in sewage sludge can also cause changes in the fertility of soil and decrease the quantity and quality of yield. The initial treatment of sewage sludge can also limit its management. For example, when liming hydrated sewage sludge, one has to take into account high increase in weight and adherence to rules used in agriculture, especially considering that such sludge is of lime and organic nature and should be used on lime fields rather than fertilizing them as it is in the case of regular sludge (Czekała, 2013).

Oxygen stabilization and conditioning are the processes that can be applied to every type of sewage sludge. They aim at changing the structure and properties of sewage sludge, thereby allowing to increase the efficiency of its dewatering (Skarżyński, 2017). The commonly employed method of sediment conditioning is polymer coagulation, which uses the high molecular weight of an organic polymer (polyelectrolyte) (Bień, Bień 2014, Bień 2017). Various methods of sediment conditioning are still being tested to increase the effect of mechanical sludge dewater- ing (Mohammad et al., 2015). A very effective method of drainage is relatively difficult and despite the use of a given technique, the final product containing less than $65 \%$ of dry matter is not achieved (Mahmoud et al., 2011). In addition, the properties of sewage sludge change, for example with the use of ultrasonic disintegration, which affects the intensification of the methane fermentation process (Zawieja, 2010) and has a significant impact on the dispersion of the sediment structure. It is increased by weakening the forces bonding water with the surface of solid phase particles, and in consequence, easier removal of water in the processes of mechanical dewatering (Bień and Wystalska, 2011). However, using aluminium and ferric salts in sludge conditioning enables to obtain the intended technological effect and at the same time increase the content of those elements in sludge. This mainly concerns aluminium, the occurrence of which in soil is especially harmful for plants (Skarżyński, 2017). It confirms that physical and chemical properties determine susceptibility of sludge to a particular type of disintegration; therefore, in the process of pre-project research, it is necessary to adapt both disintegration method and its process parameters (Zielewicz, 2016).

The research on the susceptibility to disintegration, including ultrasonic, (Sridhar et al., 2011) should include also information on participation of substances resolved in sludge since the condition for obtaining significant effects is high participation of a substance that is resolved chemically, thermally or by means of thermo-pressure (designated as COD of substances resolved in sludge liquid) in comparison to total COD (Zielewicz, 2016). At the same time, when membranes are torn to a liquid phase, enzymes and organic substances, which are easily degradable, are released (Trojanowska and Myszograj, 2017). This has a beneficial influence on the acceleration of the hydrolysis process, thereby increasing the effectiveness of the stabilization process (Bien et al., 2013; Tomczak-Wandzel et al., 2009).

Therefore, selecting the right treatment of sewage sludge is not easy. The needs and expectations of a particular sewage treatment plant (Zielewicz, 2016) are of key importance here; however, the obtained results of the carried out processes depend on a number of factors, including mainly the physical and chemical properties of sludge, which, in turn, are dependent on the properties of sewage and the manner in which it is purified. 


\section{LEGAL ISSUES}

The national formal and legal regulations concerning sewage sludge, and in particular its treatment, result from the legal requirements of the European Union. Among them, the most important are: Council Directive 86/278/EEC of 12 June 1986 on the protection of the environment, and in particular of the soil, when sewage sludge is used in agriculture, Council Directive 91/271/ EEC of 21 May 1991 concerning urban waste water treatment, Council Directive 1999/31/EC of 26 April 1999 on the landfill of waste, Directive 2006/12/EC of the European Parliament and of the Council of 5 April 2006 on waste and Council Directive 1999/31/EC of 26 April 1999 on the landfill of waste. In accordance with those acts, discharge of sewage sludge to seas and oceans and deposit of sludge on landfills is forbidden. Legal provisions prohibit the deposit of sludge with heat of combustion higher than $6 \mathrm{MJ} / \mathrm{kg}$ of dry weight, which in reality concerns the majority of sludge produced in municipal wastewater treatment plants. The directive on sludge, on the other hand, limits the employment of sewage sludge for agricultural and natural purposes. It determines the conditions that have to be met while using sewage sludge for agricultural and natural purposes. It specifies, inter alia, the maximum values for the concentration of heavy metals in soil and sludge and maximum amounts of heavy metals $(\mathrm{Cd}, \mathrm{Cu}, \mathrm{Ni}, \mathrm{Pb}, \mathrm{Zn}$ and $\mathrm{Hg}$ ), which can be applied into soil. What is more, the shortest time periods between the applications of particular sewage sludge into particular types of agricultural land and directions for usage of this land.

Under the above mentioned directives, in Poland the Act of 14 December 2012 on waste (The Act of 14 December 2012) and executive acts to this Act have been passed. The key acts in the subject of sewage sludge include: the Regulation of the Minister of Environment (Regulation of the Minister of the Environment of 6 February 2015; Regulation of the Minister of the Environment of 9 December 2014) and the Regulation of the Minister of Economy (Regulation of the Minister of Economy of 16 July 2015). In accordance with the waste catalog (Regulation of the Minister of the Environment of 9 December 2014), stabilized urban sewage sludge constitutes a group of waste with the following code: 190805 , for which the Regulation of the Minister of Economy determines a scope of tests and authorization criteria for disposal in landfills other inert waste. The scope of test and allowable limit values are related to three fundamental criteria:

- total organic carbon (TOC) $-5 \%$ of dry weight,

- loss on ignition (LOI) - 8\% of dry weight,

- heat of combustion $-6 \mathrm{MJ} / \mathrm{kg}$ of dry weight.

Taking into consideration the above mentioned conditions and recommendations of the National Waste Management Plan (Ministry of the Environment, 2016) apart from dumping, other methods of sewage sludge disposal and treatment should be taken into consideration.

Considering the agricultural and natural use of sludge, the provisions of the Act on Fertilizers and Fertilization (The Act of 10 July 2007), which differentiates between and determines different types of fertilizers and means supporting plant cultivation are recommended in particular in the case of sludge originating from small wastewater treatment plants. In accordance with the Act, organic fertilizers are the fertilizers produced from an organic substance or a mixture of organic substances, including compost. The requirements related to any types of fertilizers are regulated above all by the regulation of the Minister of Agriculture and Rural Development on the application of some regulations of the Act on fertilizers and fertilization (Regulation of the Minister of Agriculture and Rural Development of 18 June 2008). The regulation lays down the limit values for pollutants in organic fertilizers and organic-mineral and organic and organic-mineral substances supporting plant cultivation, including above all chrome, cadmium, nickel, lead and mercury. An important requirement is the point which provides that the occurrence of live eggs of intestinal parasites Ascaris sp., Trichuris sp. and Toxocara sp. and Salmonella bacteria is not allowable in fertilizers and substances supporting plant cultivation. According to the requirements of the regulation, solid organic-mineral fertilizers should contain at least $20 \%$ of organic substance calculated on the dry matter and organic fertilizers should contain at least $30 \%$ of organic substance. In addition, it determines the content of nitrogen, phosphorous and potassium in the above mentioned fertilizers.

\section{MATERIAL AND METHODS}

The sludge collected for tests came from rural and urban wastewater treatment plants, namely from a plant of size expressed by population 
equivalents lower than $2000-3$ samples and in a range from 2000 to $9999-2$ samples.

Analytical tests, enabling to characterize sludge, including determining $\mathrm{pH}$, dry residue, organic (expressed as loss on ignition) and mineral substances content (expressed as after ignition description) as well as hydration have been carried out in line with the adopted standardized test methods (Polish Standards). As part of technological test, a dewatering test has been carried out by measuring capillary suction, vacuum filtration test, sludge dewatering by means of centrifugation, concentration and ultrasonic disintegration.

The time of capillary suction consists in analyzing the process in which liquid flows from sludge to capillary of absorbent paper (Whatman -17). Time of capillary suction, expressed in seconds, indicates the transfer of a filtrate layer between designated circles with a diameter of 32 and $45 \mathrm{~mm}$ (Fukas-Płonka et al., 2013; Wolny, 2005). The measurement enables to mark changes in sludge filtration abilities, mainly in the conditioning process, and is used more often when selecting and determining doses of chemical substances (Fukas-Płonka et al., 2013; Wolny, 2005).

The tests of vacuum filtration enable to determine the speed of sludge filtration given a particular vacuum value, specific resistance of filtration, compressibility factor and the degree of filtrate contamination. The most important item characterizing vacuum filtration is specific resistance.

Dewatering by means of centrifugation has been carried out with the use of MPW-351 centrifuge for various speeds and times. Gravitational concentration of sludge, on the other hand, has been tested in cylinders with a capacity of 1000 $\mathrm{cm}^{3}$. After a defined time period $(5,15,30,60$ and 90 minutes), volume reading at the level of separating layer of concentrated sludge (at the border between sewage sludge and water) has been carried out.

Ultrasonic disintegration is considered as one of sludge conditioning methods prior to dewatering (Podedworna and Umiejewska, 2008). The main aim of disintegration is to destroy the original structure of sludge. Such deep integration in the structure of sludge enables to release the formation water and even the water bound biologically. The role of ultrasonic waves is to improve the process of sludge dewatering in the process of vacuum filtration.

The tests have been carried out with the use of SONICS ultrasonic disintegrator for samples with a volume of $100 \mathrm{~m}^{3}$, power ranging from 200 to $500 \mathrm{~W}$ and frequency of $20 \mathrm{kHz}$. The times of ultrasonic treatment and vibration amplitude have been determined experimentally for each sample of sludge individually. Particular sewage sludge has been exposed to various concentration substances, mainly Praestol, in order to determine an optimal dosage of flocculant and its type, by means of the method of coagulation.

\section{DISCUSSION OF RESULTS}

Designations of sludge from I to IV has been adopted on account of their origin - plants with increasing values of population equivalents:

- Sludge I from a sewage treatment plant with population equivalents $=907$;

- Sludge II from a sewage treatment plant with population equivalents $=1090$;

- Sludge III from a sewage treatment plant with population equivalents $=1120$;

- Sludge IV from a sewage treatment plant with population equivalents $=3491$;

- Sludge V from a sewage treatment plant with population equivalents $=5042$.

Each sewage treatment plant produces sludge with differing physical and chemical properties, but fundamental physical properties, namely colour, smell and structure of analyzed sludge were similar to each other (see Table 1). The common feature of the analyzed sludge samples was their very high or high hydration, amounting to $96.29-99.90$ and a high content of organic compounds. The percentage of organic substances varied from 54.30 to 80.49 and is very similar to typical range of organic substances content in a residual sewage sludge, which in literature ranges from 55 to $80 \%$. The $\mathrm{pH}$ values were similar to the neutral value and came within the scope of 6-7, which is typical for raw bio film (Bień and Wystalska, 2011). On the basis of time of capillary suction, which is between $25.21-187.38 \mathrm{~s}$, good dewatering properties are distinguished in four of five raw bio films.

For the collected sludge, a series of test in various options of employed dewatering, concentration and conditioning processes have been carried out. Due to the fact that the processes carried out did not affect the color, odor, content of organic and mineral substances in the next stage of the research, parameter determinations were 
Table 1. Physico-chemical characteristics of the analyzed sewage sludge

\begin{tabular}{|l|c|c|c|c|c|c|}
\hline \multicolumn{1}{|c|}{ Oznaczenie } & Unit & Sewage sludge I & Sewage sludge II & Sewage sludge III & Sewage sludge IV & Sewage sludge V \\
\hline Colour & - & brown gray & dark brown & black & brown & black \\
\hline Smell & - & specific & putrid & putrid & specific & putrid \\
\hline Structure (form) & - & fluid & $\begin{array}{c}\text { flocculent with } \\
\text { a tendency to } \\
\text { delaminate }\end{array}$ & $\begin{array}{c}\text { flocculent with } \\
\text { a tendency to } \\
\text { delaminate }\end{array}$ & fluid & fluid. uniform \\
\hline pH & - & 6.59 & 6.39 & 6.29 & 7.8 & 6.33 \\
\hline Hydration & $\%$ & 96.29 & 99.13 & 98.43 & 99.90 & 98.55 \\
\hline Dry residue & $\%$ & 3.71 & 0.87 & 1.57 & 0.10 & 1.45 \\
\hline Organic matter & $\%$ d.m. & 66.82 & 73.25 & 80.49 & 54.30 & 78.30 \\
\hline Mineral matter & $\%$ d.m. & 33.18 & 26.75 & 19.51 & 45.70 & 21.70 \\
\hline CST & S & 960.24 & 91.93 & 78.24 & 25.21 & 187.38 \\
\hline Resistivity & m/kg & $2.75 \cdot 10^{11}$ & - & - & - & - \\
\hline
\end{tabular}

made, which are the key in assessing the susceptibility of sediments to the degree of their dehydration. Prior to the commencement of the proper test, the time of ultrasonic treatment and vibration amplitude in ultrasonic disintegration of analyzed sludge was determined and an optimal dosage of flocculant was determined experimentally. The results of test of processes for particular sludge samples have been presented in Table 2. The results presented in the paper are average values obtained from min. three measurements.

In the case of all analyzed sludge (I-V), the impact of the employed treatment processes on the reduction of hydration is visible. The best results were obtained in the case of sludge 1 , in particular when vacuum filtration was used, in the course of which the content of dry weight was at the level of $28.45 \%$. Equally good effects were obtained by means of ultrasonic disintegration and a combination of those two processes. What is more, in the case of sludge I, the test of sludge dewatering on a filter confirms a positive effect of disintegration on sludge dewatering. After submitting it to conditioning by means of ultrasonic field energy, the volume of obtained sludge filtrate was after some time significantly greater than the volume of filtrate obtained from raw sludge. Under the influence of the obtained ultrasounds, the time of capillary suction was reduced by approximately $33 \%$. In parallel to those tests, vacuum filtration trials with the use of negative pressure amounting to $60 \mathrm{kPa}$ were carried out. It was shown that the analyzed sludge filtered quicker after a prior conditioning by means of ultrasounds and when pressure was higher. It was also observed that resistance of filtration decreased along with the rise in negative pressure.
In the case of sludge II, the disintegration process, as a result of ultrasonic waves, has significantly influenced the structure and properties of sludge, contributing to an increase in capillary suction time. Its influence on decreasing sludge ability to dewatering in the course of vacuum filtration has also been observed.

In the determined time, the volume of filtrate originating from raw sludge was significantly greater than in the case of the filtrate produced from the sludge which underwent disintegration (Figure 1). Considering the different duration of disintegration, the best effect was obtained for the process carried out in 1 minute. By using disintegration and then centrifuging, one can observe that the most favourable conditions for this combination occurred after 5 minutes of disintegration in a trial in which centrifuging was done with the following parameters: 5000 revolutions per minute and the length of process amounting to 20 minutes. The lower rotational speed and centrifuging time, the softer sludge cake become, which caused a noticeably worse water clarity. When centrifuging at higher speeds, sludge became denser. The concentration substance used for sludge II also caused significant stratification of sludge and improved its concentration ability.

The results of dewatering, carried out in a solid bowl centrifuge for sludge III and V, were obtained successfully and approximate to each other. A linear decline in sludge weight, which was obtained after centrifuging, along with an increasing rotational speed has been observed. Trials were carried out with the parameters considered as optimal were characterized by the best separation of phases. Cake was more dewatered and sludge water clearer. The values of obtained capillary suction times for sludge, after a disintegration lasting 
Table 2. The comparison of the results of processes carried out for sewage sludge of rural and municipal sewage treatment plants

\begin{tabular}{|c|c|c|c|c|}
\hline \multicolumn{2}{|r|}{ The origin and type of sewage sludge } & Hydration [\%] & $\begin{array}{l}\text { Dry residue } \\
{[\%]}\end{array}$ & $\mathrm{CST}[\mathrm{s}]$ \\
\hline \multirow{7}{*}{$\begin{array}{l}\text { Sewage } \\
\text { sludge I }\end{array}$} & Raw & 96.29 & 3.71 & 960.24 \\
\hline & $\begin{array}{r}\text { After dehydration in the centrifuge } 5000 \mathrm{rpm} \text {, centrifugation time } \\
20 \mathrm{~min} .\end{array}$ & 88.57 & 11.43 & - \\
\hline & $\begin{array}{l}\text { After dehydration in a centrifuge with the addition of a Praestol } \\
\text { flocculant }\end{array}$ & 88.01 & 11.99 & - \\
\hline & $\begin{array}{l}\text { After dehydration in a centrifuge after ultrasonic disintegration and } \\
\text { addition of Praestol flocculant }\end{array}$ & 78.17 & 21.83 & - \\
\hline & After ultrasonic disintegration in time: & 78.20 & 21.80 & 646.82 \\
\hline & After vacuum filtration & 71.55 & 28.45 & - \\
\hline & After vacuum filtration and ultrasonic disintegration (20s) & 74.59 & 25.41 & - \\
\hline \multirow{8}{*}{$\begin{array}{l}\text { Sewage } \\
\text { sludge II }\end{array}$} & Raw & 99.13 & 0.87 & 91.93 \\
\hline & After ultrasonic disintegration in time: & - & - & $\begin{array}{l}2264.45 \\
1711.01 \\
2470.49\end{array}$ \\
\hline & \begin{tabular}{|r|} 
After dehydration in the centrifuge $5000 \mathrm{rpm}$, centrifugation time: \\
$2 \mathrm{~min}$ \\
$5 \mathrm{~min}$ \\
$7 \mathrm{~min}$ \\
$10 \mathrm{~min}$ \\
$20 \mathrm{~min}$ \\
\end{tabular} & $\begin{array}{l}91.65 \\
90.15 \\
89.90 \\
89.51 \\
88.90\end{array}$ & $\begin{array}{c}8.35 \\
9.85 \\
10.10 \\
10.41 \\
11.10\end{array}$ & - \\
\hline & \begin{tabular}{|r|} 
After dehydration in the centrifuge $2500 \mathrm{rpm}$, centrifugation time: \\
$2 \mathrm{~min}$ \\
$5 \mathrm{~min}$ \\
$7 \mathrm{~min}$ \\
$10 \mathrm{~min}$ \\
$20 \mathrm{~min}$
\end{tabular} & $\begin{array}{l}93.45 \\
92.63 \\
92.51 \\
92.05 \\
91.40\end{array}$ & $\begin{array}{l}6.55 \\
7.37 \\
7.49 \\
7.95 \\
8.60\end{array}$ & - \\
\hline & \begin{tabular}{|r|} 
After dehydration in the centrifuge $2000 \mathrm{rpm}$. centrifugation time: \\
$5 \mathrm{~min}$ \\
$7 \mathrm{~min}$ \\
$10 \mathrm{~min}$ \\
$20 \mathrm{~min}$ \\
\end{tabular} & $\begin{array}{l}93.33 \\
93.13 \\
92.79 \\
92.14\end{array}$ & $\begin{array}{l}6.67 \\
6.87 \\
7.21 \\
7.86\end{array}$ & - \\
\hline & $\begin{array}{l}\text { After ultrasonic disintegration and centrifugation } \\
\text { (5000 rpm for } 20 \mathrm{~min} \text { ), sonication time: }\end{array}$ & $\begin{array}{l}91.35 \\
91.51 \\
89.34\end{array}$ & $\begin{array}{c}8.65 \\
8.49 \\
10.66\end{array}$ & - \\
\hline & \multirow[t]{2}{*}{$\begin{array}{l}\text { After ultrasonic disintegration and centrifugation } \\
\text { (2500 rpm for } 20 \mathrm{~min} \text { ), sonication time: }\end{array}$} & $\begin{array}{l}94.31 \\
94.61 \\
91.96\end{array}$ & $\begin{array}{l}5.69 \\
5.39 \\
8.04\end{array}$ & - \\
\hline & & 98.05 & 1.95 & 369.84 \\
\hline \multirow{3}{*}{$\begin{array}{l}\text { Sewage } \\
\text { sludge III }\end{array}$} & Raw & 98.43 & 1.57 & 78.24 \\
\hline & After ultrasonic disintegration in time: & - & - & 8521.72 \\
\hline & After concentrating the flocculant & 96.73 & 3.27 & - \\
\hline \multirow{4}{*}{$\begin{array}{l}\text { Sewage } \\
\text { sludge IV }\end{array}$} & Raw & 99.90 & 0.10 & 25.21 \\
\hline & After draining in a centrifuge for $10 \mathrm{~min}$, rpm: & $\begin{array}{l}94.91 \\
95.28 \\
95.70 \\
96.32 \\
96.71\end{array}$ & $\begin{array}{l}5.09 \\
4.72 \\
4.30 \\
3.68 \\
3.29\end{array}$ & - \\
\hline & \begin{tabular}{|r|} 
After dehydration in the centrifuge $5000 \mathrm{rpm}$, centrifugation time: \\
$5 \mathrm{~min}$ \\
$10 \mathrm{~min}$ \\
$25 \mathrm{~min}$ \\
$30 \mathrm{~min}$
\end{tabular} & $\begin{array}{l}94.30 \\
94.89 \\
94.10 \\
90.12\end{array}$ & $\begin{array}{l}5.70 \\
5.11 \\
5.90 \\
9.88\end{array}$ & - \\
\hline & $\begin{array}{|lr|}\text { After draining in a centrifuge for } 10 \min (5000 \mathrm{rpm}) \text { with the addition } \\
\text { of Flopan flocculant in an amount: } & 2.5 \mathrm{~cm}^{3} \\
1.25 \mathrm{~cm}^{3} \\
0.25 \mathrm{~cm}^{3}\end{array}$ & $\begin{array}{l}96.90 \\
95.82 \\
93.23\end{array}$ & $\begin{array}{l}3.10 \\
4.18 \\
6.77\end{array}$ & - \\
\hline \multirow{3}{*}{$\begin{array}{l}\text { Sewage } \\
\text { sludge } \vee\end{array}$} & Raw & 98.55 & 1.45 & 187.24 \\
\hline & After ultrasonic disintegration in time: & - & - & 1800.29 \\
\hline & After concentrating the flocculant & 97.68 & 2.32 & - \\
\hline
\end{tabular}




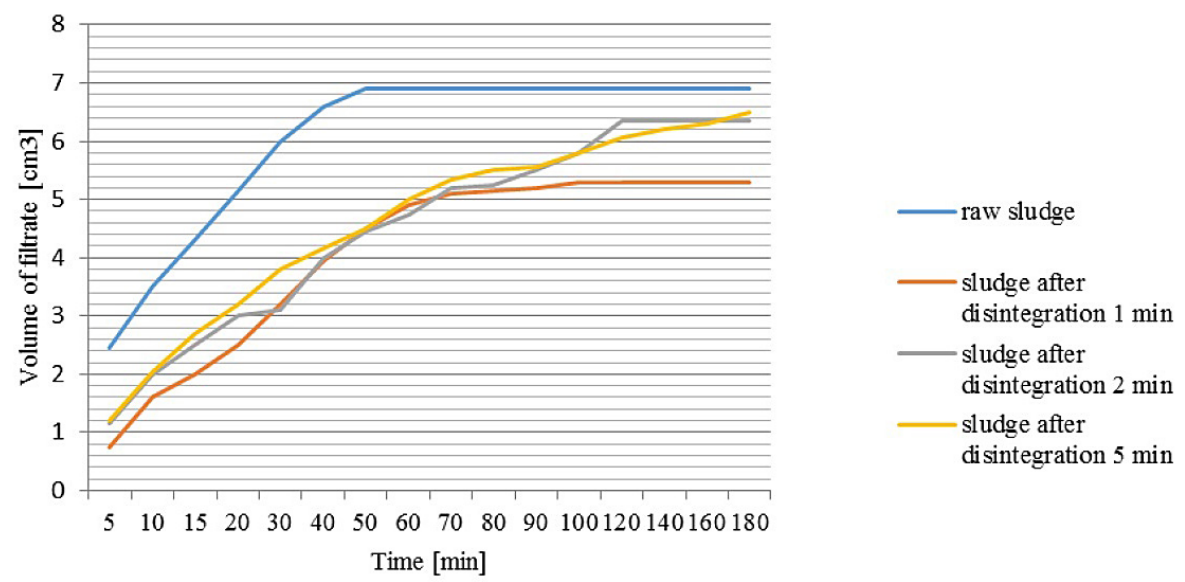

Fig. 1. Changes in the volume increase of sediment filtrate after ultrasonic disintegration

10 s (sludge III and V) are a highly visible sign of positive effect of ultrasonic field on the increase of susceptibility of sludge to dewatering.

In the case of sludge IV the best effects, namely lowering hydration by approximately $9.8 \%$, were obtained by applying centrifuging with the following parameters: 5000 revolutions per minute, centrifuging time: 30 minutes. Shortening the centrifuging time to 10 minute, while keeping the same value of revolutions per minute and adding flocculant at the same time, enabled dewatering sludge by approximately $6.7 \%$.

\section{CONCLUSIONS}

Describing the characteristics of sludge help to determine which treatment processes will be used and under what conditions. Each interference in the structure of sewage sludge influences its physical and chemical properties, which entails change of their characteristics that in turn can influence their management options.

Taking a more environmentally sound sewage sludge management - namely using it for agricultural or natural processes - and greater usefulness of sludge originating from small sewage treatment plants for those purposes, it is important to submit it to proper treatment once they are produced. The condition for choosing the right manner of sewage sludge management is its proper preliminary preparation, including dewatering, conditioning etc. The rationale for carrying out the test in various combinations of applied processes is the differing nature of sludge. If sludge is more difficult to dewater, using conditioning prior to concentration and initial dewatering is appropriate.
The research applied a number of different variants of the processes carried out, i.e. with different doses of flocculant, different time of sonication, variable revolutions and time of centrifugation. In the majority of cases, the employed processes of sludge preparation gave the intended results in the form of easier dewatering, concentration, as well as changes in some parameters. To a large extent, the obtained differences in results were due to diversified sludge properties.

1. It is confirmed that ultrasonic field as a physical method for modification of sewage sludge is a factor intensifying the dewatering processes. In the majority of cases, the tests have shown better results of dewatering of sludge submitted to ultrasonic field in comparison to raw sludge.

2. Susceptibility of sludge originating from various wastewater treatment plants to ultrasonic disintegration is very different; however, it must be stated that applying ultrasounds to sludge causes changes in their structure and influences the change in other indicators, including final hydration and capillary suction time. The lowest value of the final sludge hydration and its largest reduction was obtained for sediments subjected to vacuum filtration and ultrasonic disintegration.

3. The use of ultrasonic disintegration and centrifugation gives better results in changing hydration and dry matter than using only one of the methods.

4. Sonication of the studied sediments causes a significant increase in the CSK values. The sludge submitted to initial conditioning by means of the energy of ultrasound field release water quicker and the final amount of filtrate 
is greater than in the case of raw sludge. However, it must be remembered that the time of ultrasonic treatment and vibration amplitude has to be determined separately for each type of sludge. Excessive dose of ultrasounds can have a reverse effect than expected, which in consequence can worsen the sludge dewatering.

5. Centrifuging as a manner of mechanical concentration is justified for the analyzed sludge. It makes a significant contribution in decreasing the level of water in sludge, and therefore, increases the level of density. Precise parameters of centrifuging, namely centrifuging time and rotational speed, are of key importance.

\section{REFERENCES}

1. Bień B. 2017. The Effect of PIX 123 and Polyelectrolyte Zetag 8160 on the Conditioning and Dewatering of Sewage Sludge. Engineering and Protection of Environment, 20(2), 155-174.

2. Bień B., Bień J.D. 2014. Use of inorganic coagulants and polyelectrolytes to sonicated sewage sludge for improvement of sludge dewatering. Desalination and Water Treatment, Science and Engineering, 52/19-21, 3767-3774.

3. Bień J., Neczaj E., Worwąg M., Grosser A., Nowak D., Milczarek M., Janik M. 2011. Directions of sludge management in Poland after 2013, Engineering and Environmental Protection, 14(4), 375-384 (in Polish).

4. Bień J., Wystalska K. 2011. Sewage sludge. Theory and practice. Publishing House of Czestochowa University of Technology, Częstochowa (in Polish).

5. Czekała J. 2013. Sewage sludge dewatering - selected issues, Water supply - Sewerage, 12, 38-40 (in Polish).

6. Fukas-Płonka Ł., Janik M., Płonka I. 2013. Physical analysis of sewage sludge as a criterion of freeness. In: Manczarski P. Complex management of waste management, Poznań, 711-724 (in Polish).

7. Grobelak A., Stępień W., Kacprzak M. 2016. Sewage sludge as a component of soil fertilizers and substitutes. Ecological Engineering, 48, 52-60 (in Polish).

8. Krzywy E., Wołoszyk C., Możdżer E. 2015. Possibility of Producing Granulated Organic-Mineral Fertilizers from Some Municipal and Industrial Wastes. Chemik, 69(10), 684-697.

9. Mahmoud A., Olivier J., Vaxelaire J., Hoadley F.A. 2011. Electro-dewatering of wastewater sludge: influence of the operating conditions and their interactions effects. Water Research, 45, 2795-2810.
10. Ministry of the Environment. 2016. National Waste Management Plan 2022, Warsaw (in Polish).

11. National Water Management Authority. 2016. Report on the implementation of the National Program for Municipal Sewage Treatment in the years 2014-2015. Warsaw (in Polish).

12. Obbard J. 2001. Ecotoxicological assessment of heavy metals in sewage sludge soils, Applied Geochemistry, 16(11), 1405-1411.

13. Podedworna J., Umiejewska K. 2008. Sewage sludge technology. Publishing House of Warsaw University of Technology. Warsaw (in Polish).

14. Polish Standards. Normalization Publishers, Warsaw.

15. Regulation of the Minister of Economy of 16 July 2015 on the admission of waste for landfill. Journal of Laws, 2015, item 1277 (in Polish).

16. Regulation of the Minister of the Environment of 6 February 2015 on municipal sewage sludge. Journal of Laws, 2015, item 257 (in Polish).

17. Regulation of the Minister of the Environment of 9 December 2014 on the waste catalog. Journal of Laws, 2014, item 1923 (in Polish).

18. Regulation of the Minister of Agriculture and Rural Development of 18 June 2008 on the implementation of certain provisions of the Act on fertilizers and fertilization. Journal of Laws, 2008, No. 119, item 765 (in Polish).

19. Skarżyński S. 2017. Review of devices used in conditioning of sewage sludge with ultrasonic waves. Gas, Water and Sanitary Technique, 06/2017, 262-264 (in Polish).

20. Sridhar P., Puspendu B., Song Y., LeBlanc R.J., Tyagi R.D., Surampalli R.Y. 2011. Ultrasonic pretreatment of sludge: A review. Ultrasonics Sonochemistry, 18, 1-18.

21. Statistical Yearbooks of the Central Statistical Office. 2017. Environmental Protection 2016. Warsaw.

22. Świsłowski M. 2016. Sewage sludge utilization by granulation with lime. Gas, Water and Sanitary Technique, 03/2016, 106-110 (in Polish).

23. The Act of 14 December 2012 on waste. Journal of Laws, 2012, item 21 with later amendments (in Polish).

24. The Act of 10 July 2007 on fertilizers and fertilization. Journal of Laws, 2007, No. 147, item 1033 with later amendments (in Polish).

25. Tomczak-Wandzel R., Mędrzycka K., Cimochowicz M. 2009. The Effect of ultrasonic disintegration on sewage sludge anaerobic digestion. In: Ozonek J., Pawłowska M. (Eds). Polish Environmental Engineering five years after joining the European Union. 331 - 337 (in Polish).

26. Trojanowska K., Myszograj S. 2017. Ultrasonic disintegration of sewage sludge in GSD technolo- 
gy - operating experience. Gas, Water and Sanitary Technique, 03/2017, 110-114 (in Polish).

27. Wiater J., Butarewicz A. 2014. Ways of using sludge from Sewage Treatment Plant in Białystok. Engineering and Environmental Protection, 17(2), 281-291 (in Polish).

28. Wolny L. 2005. Ultrasonic support of the process of preparation of sewage sludge for drainage. Publishing House of Czestochowa University of Technology, Częstochowa (in Polish).

29. Zawieja I., Wolny L., Wolski P. 2010. Influence on the modification of food industry excess sludge structure on the effectiveness increase of the anaerobic stabilization process. Polish Journal of Environmental Studies, 2, 261-267.

30. Zielewicz E. 2016. Disintegration of sludge in the context of increased biogas production. Gas, Water i Sanitary Technique, 02/2016, 69-75 (in Polish).

31. Zielewicz E., Tytła M. 2015. Effects of ultrasonic disintegration of excess sludge obtained in disintegrators of different constructions. Environmental Technology, 36(17), 2210-2216. 